Journal of Thermal Engineering, Vol. 6, No. 2, Special Issue 11, pp. 92-98, March, 2020

Yildiz Technical University Press, Istanbul, Turkey

\title{
PORTABLE SOLAR DRYING SYSTEM WITH INBUILT PV MODULE FOR STANDALONE FORCED CONVECTION OPERATION
}

\author{
V. Siva Reddy ${ }^{1, *}$
}

\begin{abstract}
A portable solar drying system with inbuilt PV module has been designed, fabricated and installed at Rajeev Gandhi Memorial College of Engineering \& Technology, Nandyal, Andhra Pradesh. It is having a $1.1304 \mathrm{~m}^{2}$ absorber area and $3 \mathrm{~m}^{2}$ drying area. The dryer could accommodate 10 numbers of trays of size $0.3 \mathrm{~m}^{2}$ ). The brushless direct current (BLDC) motor fans of two $3 \mathrm{~W}$ capacity were operated directly from the energy generated by the PV panel of $10 \mathrm{~W}$ capacity installed in the solar dryer. As a part of the single batch load test performance analysis was tested using $3 \mathrm{~kg}$ of freshly harvested Fenugreek, Spinach, Chilli. After $6 \mathrm{~h}$ drying, 75 to $90 \%$ of moisture has been removed where the solar radiation intensity measured was between $600-800 \mathrm{~W} / \mathrm{m}^{2}$. Thus it is concluded that besides decreasing the overall transportation costs, the solar dryer with on-site efficient drying capability of food crops is highly beneficial in reducing the damage of produce and could retain sufficient nutrients.
\end{abstract}

\section{Keywords: Solar Dryer, PV Thermal, Forced Convection, Cost Economics}

\section{INTRODUCTION}

For several decades, sun drying was used in drying food products. It is the oldest and a well known process for preserving agricultural produce with least compromise in retaining the produce nutrient quality. Among the solar dryers, forced convection drying is the more convenient method for drying a wide variety of agricultural product. There are several reports on the methodology of thermal analysis including specific energy consumption and convective heat transfer correlations for forced convection solar drying [1-3]. However, all such systems consume electrical energy for creating desired air flow rate in the drying cabin for enhancing the rate of drying of the desired product. In addition, the grid power supply in rural and remote places of India is highly unreliable and is mostly available for few hours in a day. The electric power is primarily used for irrigation during night time and early morning hours. Thus, forced convection solar dryers have not generated much attention and interest among the rural people. Amori et al. [4] modelled a typical single pass hybrid photovoltaic/thermal (PV/T) air collector for simulation and analyses of the electrical and thermal performance. A Matlab computer simulation program was developed and validated with previously published experimental results and theoretical simulations. Barnwal and Tiwari [5] developed hybrid photovoltaic-thermal (PV/T) greenhouse dryer for experimental study where the PV panels were placed upon the green house and the power output was directly connected to the DC fan for air exhaust. Sevik [6] also reported a study on connecting solar PV system with battery bank for supply of the electrical energy to the forced convection dryer. Sarhaddi et al. [7] developed a detailed thermal and electrical model for calculating the thermal and electrical parameters of a typical PV/T air collector. An equation for the overall energy efficiency of PV/T air collector was derived in terms of thermal, electrical, design and climatic parameters and validated with previously published parametric studies.

Kumar and Rosen [8] studied PV/T air heater and found that higher packing factor was beneficial as it lead to generation of more electrical energy per unit collector area. Janjai et al.[9] developed a photovoltaic ventilated solar greenhouse dryer for drying of peeled longan and banana. The dryer consists of a parabolic roof structure covered with polycarbonate plates on a concrete base and 3 DC fans were place for ventilate the dryer. The drying time of peeled longan and banana in the solar greenhouse dryer were 3-4 days, whereas 5-6 days were required for natural sun

This paper was recommended for publication in revised form by Regional Editor Balaram Kundu

${ }^{1}$ School of Mechanical Engineering, Rajeev Gandhi Memorial college of Engineering and Technology, Nandyal-51850, India

*Email: vundelaap@gmail.com

Orcid id: ${ }^{1}$ 0000-0003-4217-6111

Manuscript Received 22 June 2018, Accepted 31 August 2018 
drying under similar conditions. Although, several, researcher groups worked on application of nanotechnology and phase change material, for the improvement of thermal performance of solar systems by enhancing heat transfer and storage capacity [10-13]. Some of the investigators studied the performance of the PV/T collector and developed correlations for the heat loss and electrical energy generation [14-17]

However, development and analysis of the PV/T forced convection solar dryers for attaining desired temperatures in the dryer cabin have not been reported till date. Keeping this in view, author's developed a solar PV module inbuilt forced convection drying facility having PV cell for generating DC power to provide energy for ventilation in dryer cabin. It results optimum utilization of open place for the same capacity solar dryer. Design and development, performance results and cost economics of the developed solar dryer were discussed.

\section{SYSTEM DESCRIPTION}

The grid independent photovoltaic module integrated forced convection portable solar drying system (Figure 1) consists of an air heating and drying in single unit. The dryer designed an inclination of $32^{\circ}$ based on the latitude $\left(15.4786^{\circ} \mathrm{N}\right)$ of place. Both the top and bottom surfaces have elliptic holes of area $0.145 \mathrm{~m}^{2}$ for effective passage of air and moisture. It contains $3 \mu \mathrm{m}$ thick UV protected sheet for filtration of UV radiation and protection of the goods from high intensity which mainly causes a drastic nutrient loss and damages the tissue. It covers the front portion of the dryer in the form of hemi-cylindrical surface (hollow) whose area is around $1.13 \mathrm{~m}^{2} .10$ Trays with iron mesh and sheet metal encasings (gas welded joints), each one of area $0.3 \mathrm{~m}^{3}$, are placed with even spatial distribution in the inner (hollow) region of the dryer whose volume is $0.4046 \mathrm{~m}^{3}$.

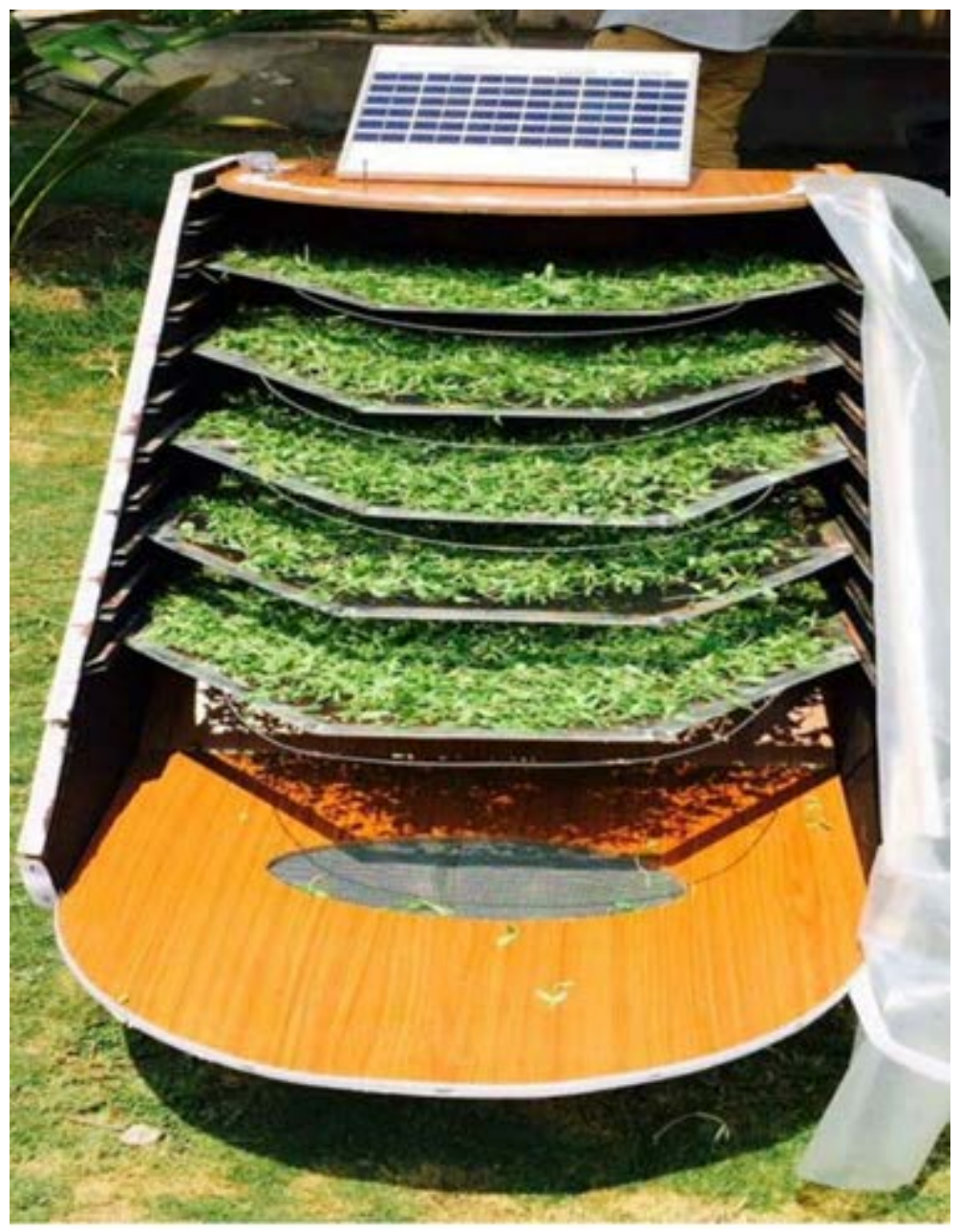

Figure 1. PV module inbuilt forced convection portable solar drying system 
The whole drying chamber is tightly enclosed with tape and small wooden reapers covering the entire edges of the UV protected sheet. One side of the sheet is removable, so that the trays can be placed inside the dryer chamber. The outlet and inlet are covered with same iron mesh that the trays are made. Two BLDC fans $(1.8 \mathrm{~W})$ are fixed at the inlet and outlet to ensure forced draught. They are powered by a PV panel of $10 \mathrm{~W}$ capacity, as it is necessary to employ a panel with 3-4 times the load. The fans run with an average of $600 \mathrm{rpm}$ and causing an outlet flow rate of air is 0.3644 $\mathrm{m}^{3}$. The technical specification of a PV cell integrated grid independent solar forced convection dryer is given in Table 1. List of instruments used to evaluate the performance of the PV integrated dryer is given in Table 2.

Table 1. Technical specifications of PV module inbuilt forced convection portable solar drying system

\begin{tabular}{|l|l|l|}
\hline Sr. No. & Parameters & Size \\
\hline 1 & Collector area & $1.1304 \mathrm{~m}^{2}$ \\
\hline 2 & Inlet & Trough the product \\
\hline 3 & Outlet & Ellipse hole of $0.145 \mathrm{~m}^{2}$ \\
\hline 4 & Tray size & $0.3 \mathrm{~m}^{2}$ (ten no.) \\
\hline 5 & Tray material & SS wire mesh placed in $\mathrm{Al}$ angle \\
\hline 6 & Loading per batch & 3 to $5 \mathrm{~kg}$ \\
\hline 7 & Drying time per batch & 1 to 1.5 days( 3 -8 hrs) \\
\hline 8 & Glazing & UV stabilized plastic sheet (200 micron thick) \\
\hline 9 & Absorber & Black painted Al sheet \\
\hline 11 & Frame work & Aluminium cylindrical bar/Powder coated Ms plate \\
\hline 12 & DC fans & $1.5 \mathrm{~W}$ (2 no) \\
\hline 14 & PV panel power & $10 \mathrm{~W}$ \\
\hline
\end{tabular}

Table 2. List of instruments used for performance analysis

\begin{tabular}{|l|l|l|l|l|}
\hline S.No & \multicolumn{1}{|c|}{ Description } & \multicolumn{1}{c|}{ Range } & \multicolumn{1}{c|}{ Accuracy } & \multicolumn{1}{c|}{ Remarks } \\
\hline 1 & Solar radiation & $\begin{array}{l}0-1500 \\
\mathrm{~W} / \mathrm{m}^{2}\end{array}$ & $20 \mu \mathrm{V} / \mathrm{W} / \mathrm{m}^{2}$ & $\begin{array}{l}\text { To measure solar } \\
\text { radiation }\end{array}$ \\
\hline 2 & PT-100 thermocouples & $0-200^{\circ} \mathrm{C}$ & $\pm 1^{\circ} \mathrm{C}$ & To measure temperature \\
\hline 3 & Hotwire anemometer & $0-40 \mathrm{~m} / \mathrm{s}$ & $\pm(3 \%+0.3 \mathrm{~m} / \mathrm{s})$ of reading & To measure air flow rate \\
\hline 4 & Multimeter meter & $\begin{array}{l}0-500 \mathrm{~V} \\
\text { and } 0-60 \mathrm{~A}\end{array}$ & $0.5 \mathrm{~V}$ and $0.5 \mathrm{~A}$ & $\begin{array}{l}\text { To measure energy } \\
\text { consumed by the BLDC } \\
\text { fans }\end{array}$ \\
\hline 5 & Solmetric PV analyzer & $\begin{array}{l}0-1000 \mathrm{~V} \\
\& 0-20 \mathrm{~A}\end{array}$ & $\begin{array}{l} \pm 0.5 \% \text { for voltage, current } \\
\pm 0.25 \mathrm{~V} \text { and } 0.04 \mathrm{~A}) \text { at } 0 \text { to } \\
55^{\circ} \mathrm{C} \text { and } \pm 2 \% \text { for irradiance }\end{array}$ & $\begin{array}{l}\text { To determine efficiency } \\
\text { of PV panel }\end{array}$ \\
\hline
\end{tabular}

\section{PERFORMANCE ANALYSIS}

\section{Efficiency Improvement Of The Pv Panel}

The increase in efficiency of the PV module was recorded throughout the day in the summer month of May and was around $9.5 \%$ by air flow at the back side of the PV module. A $5-7^{\circ} \mathrm{C}$ rise in the air temperature was recorded at $400 \mathrm{~m}^{3} / \mathrm{h}$ average mass flow rate. The performance results are shown in Table 3.

\section{Load Test}

During summer where the solar radiation was found to vary widely between 500 and $950 \mathrm{~W} / \mathrm{m}^{2}$ throughout the day, the temperature inside the drying cabin was found to vary between $45-50^{\circ} \mathrm{C}$. While during winter where the 
solar radiation was available between 250 and $650 \mathrm{~W} / \mathrm{m}^{2}$ throughout the day, the temperature inside the drying cabin was found to vary between $30-38{ }^{\circ} \mathrm{C}$. Air flow rate in the dryer cabin varied proportionally with solar radiation, because of automatic change of power input of BLDC fans that were maintained using the PV cells. Irrespective of the solar radiation, this results with minor variations in the dryer cabin temperature throughout the day.

Table 3. Performance results of PV panel with air cooling and without air cooling

\begin{tabular}{|c|c|c|c|c|c|}
\hline Time & $\begin{array}{c}\text { Energy } \\
\text { (Wh) }\end{array}$ & $\begin{array}{c}\text { Fill Factor } \\
(\%)\end{array}$ & $\begin{array}{c}\text { Solar Radiation } \\
\left(\mathrm{W} / \mathbf{m}^{2}\right)\end{array}$ & $\begin{array}{c}\text { PV Panel } \\
\text { Temperature }\left({ }^{\circ} \mathrm{C}\right)\end{array}$ & $\begin{array}{c}\text { Efficiency } \\
(\%)\end{array}$ \\
\hline \multicolumn{6}{|c|}{ With air flow } \\
\hline $11: 30$ & 98.02 & 62 & 947.33 & 69.28 & 8.62 \\
\hline $12: 30$ & 99.86 & 61 & 977.48 & 73.18 & 8.51 \\
\hline $13: 30$ & 97.17 & 61 & 961.54 & 74.31 & 8.42 \\
\hline $14: 30$ & 86.58 & 62 & 851.24 & 72.14 & 8.48 \\
\hline $15: 30$ & 69.98 & 64 & 678.61 & 66.68 & 8.60 \\
\hline Total & 451.63 & & 5299.46 & & 8.52 \\
\hline \multicolumn{6}{|c|}{ Without air flow } \\
\hline $11: 30$ & 86.2 & 60 & 910.37 & 81.49 & 7.89 \\
\hline $12: 30$ & 89.38 & 59 & 966.25 & 87.43 & 7.71 \\
\hline $13: 30$ & 85.09 & 59 & 935.80 & 88.33 & 7.57 \\
\hline $14: 30$ & 73.82 & 61 & 797.14 & 85.40 & 7.71 \\
\hline $15: 30$ & 59.13 & 63 & 608.69 & 74.68 & 8.09 \\
\hline Total & 393.63 & & 5061.92 & & 7.78 \\
\hline
\end{tabular}

\section{Fenugreek}

Due to high water content in Fenugreek compared to other leafy products (Spinach), the moisture removed was $91.41 \%$ (i.e., $1.172 \mathrm{~kg}$ ) in a span of $4 \mathrm{~h}$. It has an average product temperature rise of $16^{\circ} \mathrm{C}$ with a dryer efficiency is $27.4 \%$ (Table 4 ).

\section{Spinach}

Due to its high surface area and water density (i.e., less than Fenugreek) is only next to Fenugreek with moisture removal of $74.94 \%$ (i.e., $0.682 \mathrm{~kg}$ ) in a span of $4 \mathrm{~h}$. It has an average temperature rise of $16^{\circ} \mathrm{C}$ with the dryer efficiency of 35.94\% (Table 4).

Table 4. Full load performance results

\begin{tabular}{|l|l|l|l|l|}
\hline Sample & Before drying (kg) & After drying (kg) & Moisture removed (\%) & Efficiency (\%) \\
\hline Fenugreek & 1.282 & 0.110 & 91.41 & 27.24 \\
\hline Spinach & 0.910 & 0.228 & 74.94 & 35.94 \\
\hline Chilli & 1.365 & 0.206 & 84.9 & 14.16 \\
\hline
\end{tabular}

\section{Chilli}

Due to the low water content and surface area, chilli takes more heat and time to remove same amount of moisture as that of leafy products. Chili has a moisture removal of $84.9 \%$ (i.e., $1.159 \mathrm{~kg}$ ) in a span of $6 \mathrm{~h}$. It has an 
average temperature rise of $20^{\circ} \mathrm{C}$ with the dryer efficiency of $14.16 \%$. An image of the product before and after solar drying is shown in Figure 2.

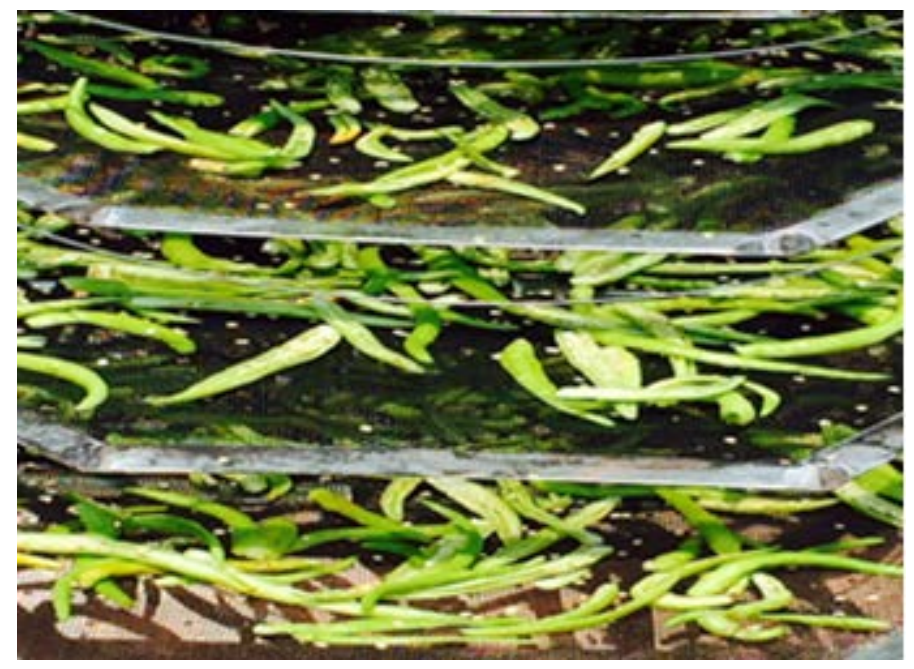

(a)

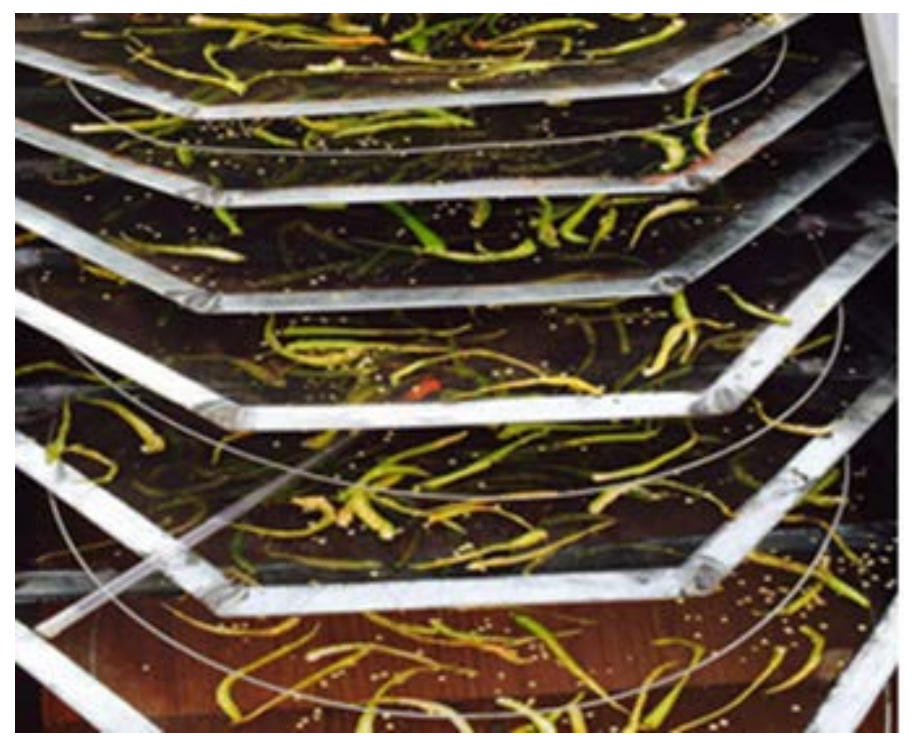

(b)

Figure 2. Photographs of Chilli (a) before drying and (b) after drying

\section{ECONOMIC ANALYSIS}

Economic analysis of the solar dryer was performed to calculate the payback period after load test experiments, which could be helpful in expediting the utilization of PV module inbuilt forced convection portable solar drying system in rural areas of India. Cost estimation and economic analysis of the PV module inbuilt forced convection portable solar drying system is detailed in Table 5, where the cost of the system including PV cells and BLDC fans was calculated to be nearly INR 10, 000/-. The estimates were calculated based on the developed solar dryer system, where approximately $2 \mathrm{~kg}$ of water could be evaporated from the product at $5.5 \mathrm{kWh} / \mathrm{day} / \mathrm{m}^{2}$ solar radiation. The payback period of the developed system with substitute of electrical based dryer was calculated to be within 3.5 years at 250 working days per year. 
Table 5. Cost estimations of the PV module inbuilt forced convection portable solar drying system

\begin{tabular}{|l|l|l|l|}
\hline Sr. No. & Description & PV -Solar Dryer & Electrical Dryer \\
\hline 1 & Cost, Rs. & 10000 & 3000 \\
\hline 2 & Useful life in years & 10 & 10 \\
\hline 3 & Loading capacity, kg/day & $3-5$ & $3-5$ \\
\hline 4 & Thermal Capacity, kg of water removal/day & 2 & 2 \\
\hline 5 & Working day per year & 250 & 250 \\
\hline 6 & Product dried, kg/year & 750 & 750 \\
\hline 7 & Electrical consumption for Blower kWh/day & 0 & 0.032 \\
\hline 10 & Annual interest rate, \% & 12 & 12 \\
\hline 11 & Annual repair and maintenance,\% of cost & 5 & 2 \\
\hline Annual Cost, INR. & & \\
\hline 12 & Interest on average cost & 1200 & 360 \\
\hline 13 & Depreciation @ 9\%,Rs./year & 900 & 270 \\
\hline 14 & Repair and maintenance & 500 & 60 \\
\hline Sub Total Rs./year & 2600 & 690 \\
\hline Rs./day & & 11 & 3 \\
\hline Operating Cost, INR. & & \\
\hline 15 & Electricity @ Rs. 8/kWh & 0 & $16+0.26$ \\
\hline & Sub Total Rs./year & 0 & 4065 \\
\hline \multicolumn{2}{|l|}{ Rs./day } & 0 & 16.26 \\
\hline Cost of Drying & Rs./year & 2750 & \\
\hline & Rs./day & 11 & 4815 \\
\hline & Rs./kg & 3.66 \\
\hline
\end{tabular}

\section{CONCLUSION}

The increase in efficiency of the PV module recorded throughout the day in a summer month was around 9.5 $\%$ by air flow at the back side of the module. Irrespective of solar radiation, the system shows minor variations in the temperature of the dryer cabin throughout the day. The payback period of system as compared to electrical based dryer was found to be 3.5 years. Utilizing the advantage of drastic reduction of solar PV cost, a commercially viable option to meet the needs of the forced convection solar drying system in rural areas is advocated through this study.

\section{ACKNOWLEDGEMENT}

Investigator gratefully acknowledge financial support provided by Science and Engineering Research Board, Department of Science and Technology, Government of India.

\section{NOMENCLATURE}

BLDC

PNG

PV

$\Delta \mathrm{T}$
Brushless Direct Current

Pipeline Natural Gas

Photovoltaic

Temperature Difference 


\section{REFERENCES}

[1] Nayak S, Tiwari GN. Energy and exergy analysis of photovoltaic/thermal integrated with a solar greenhouse. Energy and Buildings 2008; 40: 2015-2021. doi:10.1016/j.enbuild.2008.05.007.

[2] Rathore NS, Panwar NL. Experimental studies on hemi cylindrical walk-in type solar tunnel dryer for grape drying. Applied Energy 2010; 87: 2764-2767. doi:10.1016/j.apenergy.2010.03.014.

[3] Singh S, Kumar S. Testing method for thermal performance based rating of various solar dryer designs. Solar Energy 2012; 86: 87-98. doi:10.1016/j.solener.2011.09.009.

[4] Amori KE, Hussein M, Al-Najjar T. Analysis of thermal and electrical performance of a hybrid (PV/T) air based solar collector for Iraq. Applied Energy 2012; 98:384-395. doi:10.1016/j.apenergy.2012.03.061.

[5] Barnwal P, Tiwari GN. Grape drying by using hybrid photovoltaic-thermal (PV/T) greenhouse dryer: An experimental study. Solar Energy 2008; 82: 1131-1144. doi:10.1016/j.solener.2008.05.012.

[6] Sevik S. Experimental investigation of a new design solar-heat pump dryer under the different climatic conditions and drying behavior of selected products. Solar Energy 2014; 105: 190-205. doi:10.1016/j.solener.2014.03.037.

[7] Sarhaddi F, Farahat S, Ajam H, Behzadmehr A, Adeli M. An improved thermal and electrical model for a solar photovoltaic thermal (PV/T) air collector. Applied Energy 2010; 87: 2328-2339. doi:10.1016/j.apenergy.2010.01.001

[8] Kumar R, Rosen MA. Performance evaluation of a double pass PV/T solar air heater with and without fins. Applied Thermal Engineering 2011; 31: 1402-1410. doi:10.1016/j.applthermaleng.2010.12.037.

[9] Janjai S, Lamlert N, Intawee P, Mahayothee B, Bala BK, Nagle M, Muller J. Experimental and simulated performance of a PV-ventilated solar greenhouse dryer for drying of peeled longan and banana. Solar Energy 2009; 83: 1550-1565. doi:10.1016/j.solener.2009.05.003.

[10] Hussein AK. Application of Nanotechnology in Renewable Energies-A comprehensive overview and understanding. Renewable and Sustainable Energy Reviews 2015; 42: 460-476. doi:10.1016/j.rser.2014.10.027

[11] Hussein AK, Walunj A, kolsi L. Applications of Nanotechnology to enhance the performance of the direct absorption solar collectors. Journal of Thermal Engineering 2016; 2: 529-540. doi:10.18186/jte.46009.

[12] Li D, Li Z, Zheng Y, Liu C, Hussein AK, And Liu X. Thermal performance of a PCM-filled double glazing unit with different termo-physical parameters of PCM. Solar energy 2016; 133: 207-220. doi:10.1016/j.solener.2016.03.039.

[13] Hussein AK. Applications of nanotechnology to improve the performance of solar collectors-Recent advances and overview. Renewable and Sustainable Energy Reviews 2016; 62: 767-792. doi:10.1016/j.rser.2016.04.050.

[14] Hussein AK, Li D, kolsi L, Kata S, Sahoo B. A review of nano fluid role to improve the performance of the heat pipe solar collectors. Energy Procedia 2017; 109 : 417-424. doi:10.1016/j.egypro.2017.03.044.

[15] Tyagi VV, Kaushik SC, Tyagi SK. Advancement in solar photovoltaic/thermal (PV/T) hybrid collector technology. Renewable and Sustainable Energy Reviews 2012; 16: 1383-1398. doi:10.1016/j.rser.2011.12.013.

[16] Yusof MH, Othman, Yatim B, Sopian K, Mohd NAB. Performance analysis of a double-pass photovoltaic/thermal (PV/T) solar collector with CPC and fins. Renewable Energy 2005; 30: 2005-2017. doi:10.1016/j.renene.2004.10.007.

[17] Zhang X, Zhao X, Smith S, Xu J, Yu X. Review of R\&D progress and practical application of the solar photovoltaic/thermal (PV/T) technologies. Renewable and Sustainable Energy Reviews 2012; 16: 599-617. doi:10.1016/j.rser.2011.08.026. 